\title{
IMPACT-INDUCED CHEMICAL REACTION BEHAVIOR OF ZrTiNiCuBe BULK METALLIC GLASS FRAGMENTS IMPACTING ON THIN PLATES
}

\author{
UDARNO INDUCIRANA KEMIČNA REAKCIJA DROBCEV \\ ZrTiNiCuBe MASIVNEGA KOVINSKEGA STEKLA OB \\ UDARJANJU NA TANKE PLOŠČE
}

\author{
Xi Chen, Chengxin Du, Chun Cheng, Zhonghua Du, Nianqiao Pan \\ Nanjing University of Science and Technology, School of Mechanical Engineering, no. 200 Xiaolingwei Street, Xuanwu District, \\ Nanjing, 210094, China \\ chenxi@njust.edu.cn
}

Prejem rokopisa - received: 2018-04-27; sprejem za objavo - accepted for publication: 2018-06-14

doi: $10.17222 / \mathrm{mit} .2018 .089$

\begin{abstract}
The impact-induced chemical reaction behavior of ZrTiNiCuBe bulk metallic glass was investigated by ballistic impact experiments. The Zr-based metallic glass fragments were launched at different initial velocities to normally impact 08 low-carbon steel plates with different thicknesses. The impact-induced deflagration was observed, and the shock wave overpressure after the target and the damage patterns of the thin plates were measured and analyzed. As the results show, the impact-induced chemical reaction is co-determined by the impact velocity and the thickness of the plate. The higher the impact velocity and the thinner the plate, the higher the shock wave overpressure and energy release rate due to a more intense chemical reaction. The damage pattern of ductile reaming was formed and the radial reaming effect is obvious due to the chemical energy released during the penetration. Moreover, combining theoretical considerations with experimental results, the engineering models of the shock wave pressure and the deflection were developed, the calculated results agree well with the experimental data, which can provide a reliable basis for the evaluation of the impact response and energy release of the $\mathrm{Zr}$-based metallic glasses.

Keywords: Zr-based bulk metallic glass fragment, impact-induced chemical reaction, shock wave overpressure, energy release
\end{abstract} characteristics

S pomočjo balističnega udarnega eksperimenta so avtorji prispevka raziskovali udarno inducirano kemijsko reakcijo masivnega kovinskega stekla iz zlitine na osnovi ZrTiNiCuBe. Avtorji raziskave so z drobci kovinskega stekla na osnovi Zr bombardirali jeklene plošče različne debeline z različno začetno hitrostjo. Na tarči so opazovali udarno inducirane eksplozije in nadtlak udarnih valov. Izmerili in analizirali so vzorce nastalih poškodb na tankih jeklenih ploščah. Rezultati analiz so pokazali, da je obseg udarno inducirane kemične reakcije odvisen od hitrosti udarca in debeline jeklene plošče. Višja kot je hitrost udarca in tanjša kot je plošča, višji je nadtlak udarnega vala in hitrost sprostitve energije zaradi bolj intenzivne kemične reakcije. Nastali vzorci poškodb so imeli obliko duktilne vrtine in radialni vrtilni efekt so pripisali sproščeni kemični energiji med penetracijo drobcev. Nadalje so avtorji kombinirali teoretična spoznanja z eksperimentalnimi rezultati in razvili inženirske modele za tlak udarnih valov in deformacije zaradi upogibanja. Izračuni se dobro ujemajo z eksperimentalnimi podatki, kar predstavlja zanesljivo osnovo za ovrednotenje udarnega odgovora in sprostitve energije kovinskih stekel na osnovi Zr.

Ključne besede: delci masivnega kovinskega stekla na osnovi $\mathrm{Zr}$, udarno inducirana kemična reakcija, nadtlak udarnih valov, značilnosti sproščanja energije

\section{INTRODUCTION}

Bulk metallic glasses (BMGs) have large geometric dimensions, generally above a millimeter. In the solid state, the atoms of metallic glass are arranged in a topological disorder in three-dimensional space, but this structure can remain relatively stable in a certain temperature range, ${ }^{1}$ which is distinctly different from conventional crystalline metals. Therefore, bulk metallic glasses have superior physical and mechanical properties, such as high strength, high hardness, good fracture toughness, wear resistance and corrosion resistance, which are widely applied in aerospace, machinery, telecommunications, automobile and military fields. ${ }^{2,3}$ Owing to the high glass-forming ability and stability, Zr-based bulk metallic glasses are a rapidly developing group of bulk metallic glasses. At present, much progress has been achieved, mainly in their formulation and fabrication, ${ }^{4,5}$ deformation and fracture mechanisms, ${ }^{6,7}$ shear bands and shear-banding temperature rises, ${ }^{8,9}$ the effects of the addition of other alloying elements on the properties of Zr-based metallic glass, ${ }^{10,11}$ mechanical properties and-strain rate effects. ${ }^{12-14}$

The energetic properties of Zr-based metallic glasses have also been investigated. M. Q. Jiang et al. ${ }^{15}$ reported $\mathrm{Zr}_{41.2} \mathrm{Ti}_{13.8} \mathrm{Cu}_{12.5} \mathrm{Ni}_{10.0} \mathrm{Be}_{22.5}$ bulk metallic glass after ns-pulse laser loading experienced an explosion-type vaporization, where some high-temperature matter was ejected from the target surface in the form of sparks. $\mathrm{H}$. L. Ren et al. ${ }^{16}$ studied the dynamic compression properties of various W/Zr alloys with SHPB experiments, the results revealed the violent reaction of $\mathrm{W}$ and $\mathrm{Zr}$ when 
subjected to shock loading and produced a clear flame. C. M. Huang et al. ${ }^{17}$ investigated the quasi-static and impact-initiated response of $\mathrm{Zr}_{55} \mathrm{Ni}_{5} \mathrm{Al}_{10} \mathrm{Cu}_{30}$ alloy, it can be initiated by a ballistic impact and then completely burned in air. P. G. Luo et al. ${ }^{18}$ studied the impactinitiated reaction behavior of $\mathrm{W} / \mathrm{Zr}$-based metallic glass composites by a quasi-sealed test chamber, the results showed that the reaction of $\mathrm{W} / \mathrm{Zr}$ energetic fragments is related to the shock energy, which is codetermined by the impact velocity, materials and thickness of the plate. However, compared with the traditional energetic materials, such as thermite mixtures, metal polymers, intermetallic compounds, the reaction type and mechanism of Zr-based metallic glasses are different. Zr-based metallic glasses have a higher energy existing in metastable state, large negative mixing enthalpy among their major constituent elements, the atomic self-propagation occurs at high temperature and high pressure, which can activate the chemical exothermic reaction. ${ }^{19}$ Therefore, during high-speed impact, Zr-based metallic glasses will produce very complicated mechanical and chemical coupling responses, especially the influence of the chemical reaction on the impact behavior and the energy release characteristics during impacting, which are difficult to understand and less well known.

In this work, the ballistic impact experiments are conducted to understand the influences of impact velocity and thickness of the thin plate on the impact-induced chemical reaction behavior of the Zr-based metallic glass fragments. Furthermore, through an analysis of the shock wave pressure and the damage effect of the plate, the energy-release characteristics of the Zr-based metallic glass fragments during penetration are discussed.

\section{EXPERIMENTAL PART}

\subsection{Preparation of Zr-based metallic glass fragments}

The amorphous material used for the impact experiments was made of high-purity metals $(41.2 \% \mathrm{Zr}$, $13.8 \% \mathrm{Ti}, 12.5 \% \mathrm{Cu}, 10.0 \% \mathrm{Ni}$, and $22.5 \% \mathrm{Be}, w / \%)$ and was repeatedly melted by a tungsten arc furnace. Using copper mold casting, the Zr-based metallic glass specimens were prepared in the form of cylindrical fragments with dimensions of $8 \mathrm{~mm}$ in diameter and $8 \mathrm{~mm}$ in height. The mass and density of the Zr-based metallic glass fragment are approximately $2.3 \mathrm{~g}$ and $5.8 \mathrm{~g} \mathrm{~m}^{-3}$, respectively. In order to launch the fragment from a smooth bore artillery, $25 \mathrm{~mm}$ in diameter, the structure of sub-caliber fragment projectile was designed, as shown in Figure 1. The fragment was encapsulated in three aluminum sabots, $35 \mathrm{CrMnSiA}$ steel spacer block and a nylon bottom pusher.

\subsection{Experimental methods}

A scheme of the experimental setup is shown in Figure 2. The distance between the muzzle and the thin

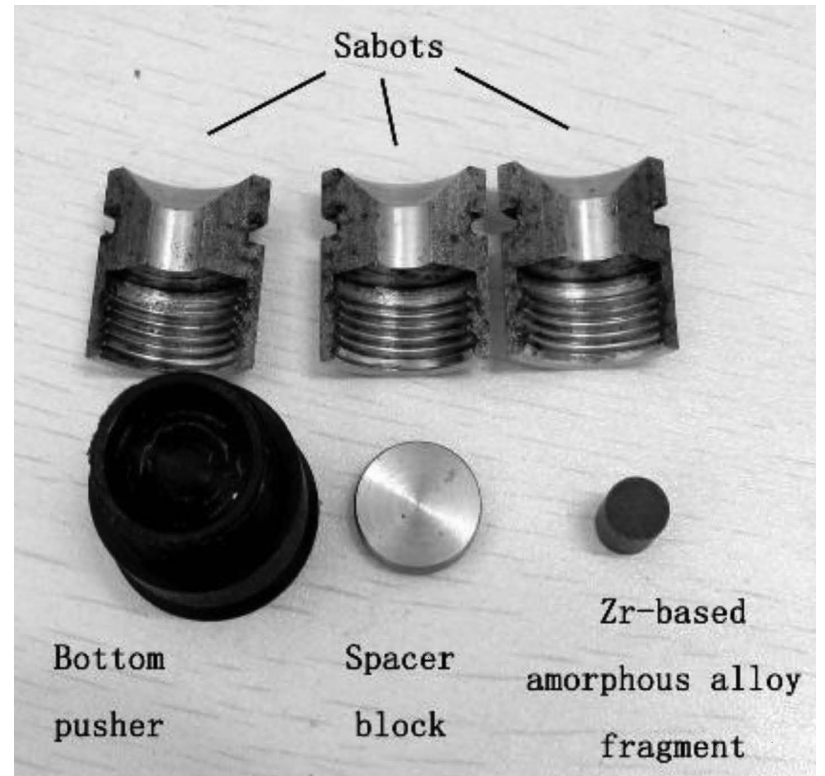

Figure 1: Photograph of projectile components

plate was $10 \mathrm{~m}$. The impact velocities of the fragments were measured using two paper targets, at a distance of $6 \mathrm{~m}$ from the muzzle. The distance is enough to ensure the sabots can be separated from the fragment by air resistance during the flight. The initial velocity of the fragment was controlled by adjusting the amount of propellant. The target 08 low-carbon steel plates with thicknesses of $2 \mathrm{~mm}, 3 \mathrm{~mm}$ and $4.5 \mathrm{~mm}$ were used in the experiments. Their size was $300 \mathrm{~mm} \times 300 \mathrm{~mm}$. The strain-type pressure sensor was used to measure the pressure-time curve of the shock wave after the target, at a distance of $600 \mathrm{~mm}$ from the thin plate. The process of Zr-based metallic glass fragments impacting thin plates was recorded by high-speed video camera.

\section{RESULTS}

Table 1 gives the experimental data of $\mathrm{Zr}$-based metallic glass fragments impacting steel plates with different thicknesses at different initial velocities. When Zr-based metallic glass fragments impact thin plates, the shock wave is generated instantaneously, as a consequence of the released energy of the chemical reaction,

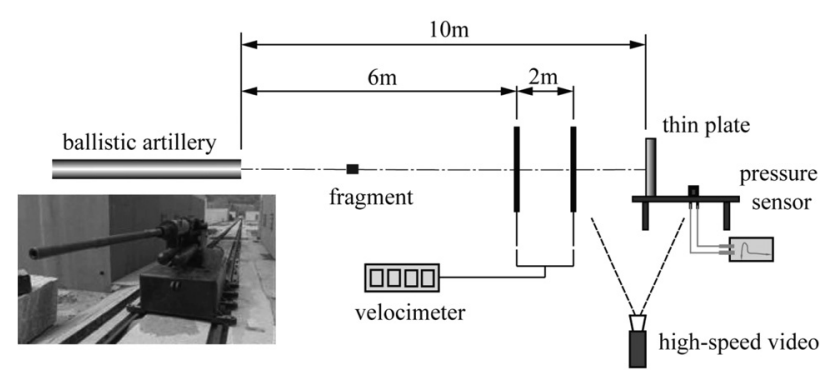

Figure 2: Schematic diagram of the experiment layout. 
initiated by the impact. Therefore, the sensor measured the propagation and attenuation processes of the shock wave in the air after the thin plates. According to the initial peak of the measured pressure-time curve, the overpressure value of the shock wave can be obtained. As shown in Table 1, the overpressure values at the $2^{\text {nd }}$ and $3^{\text {rd }}$ shots are 2 and 2.5 times the overpressure value in other cases, respectively, and the corresponding impacting reaction is more intense, as shown in Figure 4. When the thickness of the plates is the same, the overpressure increases with an increasing of the impact velocity, indicating that the released chemical energy increases, the energy release rate is affected by the impact velocity. Meanwhile, the pressure of the shock wave is related to the thickness of plates. Comparing the results of the $1^{\text {st }}, 3^{\text {rd }}$ and $5^{\text {th }}$ experiments, the overpressure value of the shock wave is the largest in the case of the $3^{\text {rd }}$ fragment, although its plate is the thinnest and the impact velocity is the lowest.

Table 1: Experimental results

\begin{tabular}{|c|c|c|c|c|c|}
\hline Shot\# & $\begin{array}{c}\text { Target } \\
\text { thickness } \\
(\mathrm{mm})\end{array}$ & $\begin{array}{c}\text { Impact } \\
\text { velocity } \\
\left(\mathrm{m} \mathrm{s}^{-1}\right)\end{array}$ & $\begin{array}{c}\text { Pressure } \\
\text { peak } \\
(\mathrm{MPa})\end{array}$ & $\begin{array}{c}\text { Reaming } \\
\text { radius } \\
(\mathrm{mm})\end{array}$ & $\begin{array}{c}\text { Deflection } \\
(\mathrm{mm})\end{array}$ \\
\hline 1 & 3 & 1450 & 0.02 & $7-10$ & $10-15$ \\
\hline 2 & 3 & 1560 & 0.04 & $10-15$ & $15-20$ \\
\hline 3 & 2 & 1348 & 0.05 & $20-25$ & $20-25$ \\
\hline 4 & 2 & 1218 & 0.024 & $8-12$ & $10-15$ \\
\hline 5 & 4.5 & 1630 & 0.021 & $7-10$ & $8-10$ \\
\hline
\end{tabular}

The damage caused by the Zr-based metallic glass fragment impact is quantified using the parameters of reaming radius and deflection. Figure 3 shows typical photographs of front and back views of thin plates impacted by fragments. When the thickness of the plate is $2 \mathrm{~mm}$ and $3 \mathrm{~mm}$, a damage pattern of ductile reaming can be observed, as shown in Figure 3a to 3c. The front

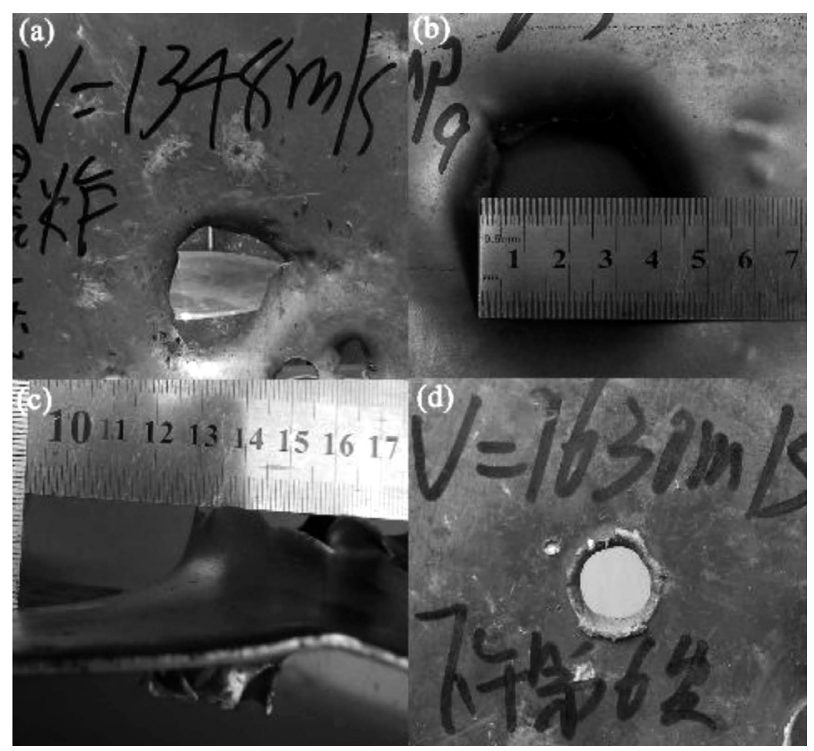

Figure 3: Typical photographs of perforated thin plates of the thin plate is concave and the back is flanged, without obvious shear failures. The back of the thin plate has a distinct blue and ablation (Figure 3b), which shows a chemical reaction is produced by Zr-based metallic glass fragments impacting thin plates, that releases a lot of heat and generates a large temperature rise. Table 1 also shows that the diameter of the perforated hole is about 5 times the diameter of the fragment, which is much larger than that penetrated by an inert steel fragment. This further explains that the chemical reaction can lead to a radial reaming effect while penetrating the thin plate. However, the shear plugging fracture is typically formed in the impacted the plate with a thickness of $4.5 \mathrm{~mm}$, as shown in Figure 3d, a gray rough cylindrical hole is observed. It is considered that the increase of the thickness of the plate and no chemical reaction of the Zr-based metallic glass fragments are caused.

Typical high-speed video frames of Zr-based metallic glass fragments impacting $2 \mathrm{~mm}, 3 \mathrm{~mm}$ and $4.5 \mathrm{~mm}$ steel plates are shown in Figure 4. When the fragment impacts the thin plate, the flame with a certain brightness and duration appears in the plane of the plate. It is an impact-induced deflagration phenomenon, which indicates the Zr-based metallic glass fragment occurs in a chemical reaction and releases energy. For the same thickness of plates, the time and degree of the chemical reaction are different at different impact velocities, as shown in Figure $\mathbf{4 c}$ and $\mathbf{4 d}$. The impact velocity increase

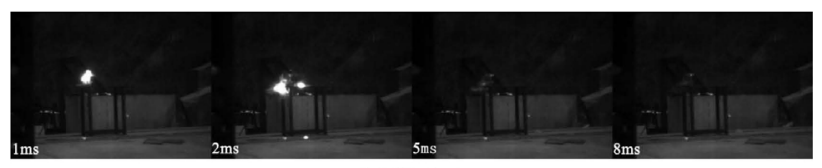

(a) \#1 shot
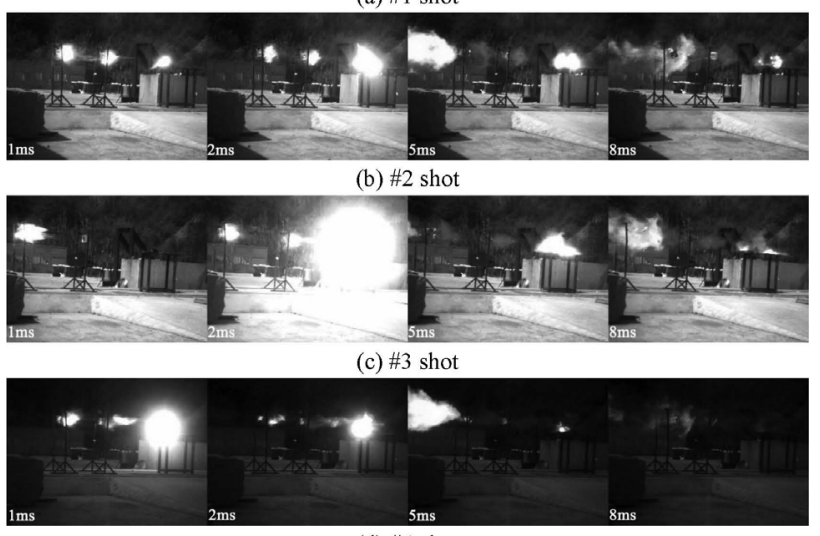

(d) \#4 shot

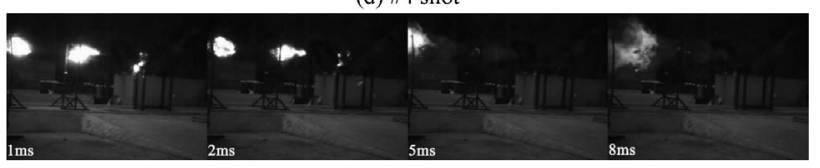

(e) \#5 shot

Figure 4: Typical high-speed video frames: a) 3-mm-thick plate impacted at $1450 \mathrm{~m} \mathrm{~s}^{-1}$, b) 3-mm-thick plate impacted at $1560 \mathrm{~m} \mathrm{~s}^{-1}$, c) 2-mm-thick plate impacted at $1348 \mathrm{~m} \mathrm{~s}^{-1}$, d) 2 -mm-thick plate impacted at $1218 \mathrm{~m} \mathrm{~s}^{-1}$, e) 4.5 -mm-thick plate impacted at $1630 \mathrm{~m} \mathrm{~s}^{-1}$ 
results in a greater brightness and increased duration of the flame. Furthermore, the attenuation effect of the shock wave and the damage of the plate are different. In the case of impacting a thinner plate at a lower velocity, the brightness and duration of the flame are larger than those with a thicker plate and a higher velocity, as shown in Figure $\mathbf{4 b}$ and $\mathbf{4 c}$. Therefore, the impact reaction of Zr-based metallic glass fragments is closely related to the impact velocity of the fragment and the thickness of the thin plate. More intense impact behavior and energy release were observed in the case of the thin plate.

\section{DISCUSSION}

Combining the high-speed video analysis, the impact process can be divided into three main stages, as shown in Figure 5. In the first stage (Figure 5a), the Zr-based metallic glass fragment undergoes high-stain-rate plastic deformation, and begins to ignite. Meanwhile, the thin plate also undergoes plastic deformation in the impact region of the fragment, and there is a gradient of temperature and stress on the plate. The shock waves produced by the impact propagate forward into the plate and backward into the fragment. In the second stage (Figure 5b), the Zr-based metallic glass fragment is enhanced initiation during penetration, resulting in partial deflagration, and a localized flame is formed in the impact region. The chemical reaction of the $\mathrm{Zr}$-based metallic glass fragment is as $\mathrm{Zr}+\mathrm{O}_{2} \rightarrow \mathrm{ZrO}_{2},{ }^{19}$ the oxygen is consumed in sn exothermal reaction with $\mathrm{Zr}$. The energy is released after impact due to the combustion of $\mathrm{Zr}$ particles, which is responsible for the shock wave. In this case, the deformation of the thin plate is more severe due to the superposition of the shock wave, reflection wave and stress wave, the thin plate is extruded into the hole along the contact face of the fragment. In the reverse direction of the reflected wave, many tiny particles escape from the boundary between the fragment and the plate. In the third stage (Figure 5c), the initiated Zr-based metallic glass fragment continues to deflagrate and release the chemical energy. The debris is ejected around the back of the plate. Under the combined effects of kinetic and chemical energy, the diameter of the

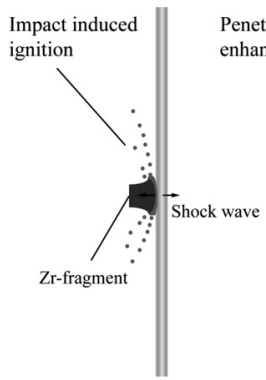

(a)

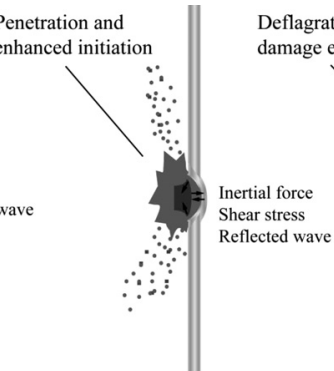

(b)

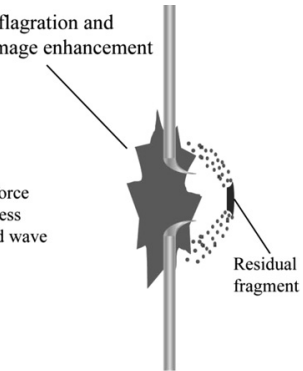

(c)
Figure 5: The process of Zr-based metallic glass fragment impacting the thin plate: a) the first stage, b) the second stage and c) the third stage perforated hole is much larger than the diameter of the fragment.

It can be seen that it is a process of coupling explosion and impact, and is accompanied by the propagation of shock waves, the tensile deformation of the plate, the expansion of cracks, the fragment broken, and the heat generation and energy release. The energy is released instantaneously by the chemical reaction of the Zr-based metallic glass fragment in the form of shock waves, so the damage effects to the thin plate can be divided into the superposition of the damage caused by the shock wave produced by the impact effect and the chemical reaction of the fragment. In engineering, the damage effects can be characterized by the reaming radius and the deflection, and thus the amount and behavior of released energy of Zr-based metallic glass fragment impacting the thin plate can be estimated.

\subsection{Shock wave pressure}

It is considered that the work done by the shock wave and the damage caused by the fragment impact are all converted into the plastic deformation energy of the thin plate. For the thin plate (when $R / h_{\mathrm{t}} \approx 8$ ), the total plastic work is obtained by using Thomson plastic reaming theory. ${ }^{20}$

$$
W(R)=0.5 \pi R^{2} h_{\mathrm{t}} \sigma_{y}
$$

where $R$ is the reaming radius, and $h_{\mathrm{t}}$ and $\sigma_{Y}$ are the thickness and the yield stress of the thin plate, respectively.

For the damage caused by the impact of the Zr-based metallic glass fragment, it is necessary to consider the influence of the inertial force and the frictional force that the fragment suffers during the penetration of the thin plate. The inertial force is caused by the acceleration of the plate material after extrusion, the amount of work done against the inertial force is equal to the increase in the kinetic energy of the plate block chiseled-off the thin plate. The mass of the plate block is written as $M=\pi r^{2} \rho_{\mathrm{t}} h_{\mathrm{t}}$, where $\rho_{\mathrm{t}}$ is the density of the plate material and $r$ is the radius of the penetration hole. It is clear that the inertia force gradually increases as the reaming radius increases. The inertia force in the reaming process can be written as:

$$
F=\frac{\mathrm{d}}{\mathrm{d} t}\left(M \frac{\mathrm{d} r}{\mathrm{~d} t}\right)
$$

So the work done to overcome the inertial forces can be expressed as in reference: ${ }^{21}$

$$
\begin{aligned}
& W_{\mathrm{G}}=\int_{0}^{R} F \mathrm{~d} r=\int_{0}^{R}\left(M \frac{\mathrm{d}^{2} r}{\mathrm{~d} t^{2}}+\frac{\mathrm{d} M}{\mathrm{~d} t} \frac{\mathrm{d} r}{\mathrm{~d} t}\right) \mathrm{d} r \\
& =\pi \rho_{\mathrm{t}} h_{\mathrm{t}} \int_{0}^{R} r^{2} \frac{\mathrm{d}^{2} r}{\mathrm{~d} t^{2}} \mathrm{~d} r+2 \pi \rho_{\mathrm{t}} h_{\mathrm{t}} \int_{0}^{R} r\left(\frac{\mathrm{d} r}{\mathrm{~d} t}\right)^{2} \mathrm{~d} r+
\end{aligned}
$$

For another influencing factor, the friction resistance is that the plate continuously cuts the adhesive force dur- 
ing the reaming process of the fragment, and it is numerically equal to the sliding yield shear stress of the plate. Based on the Von-Mises yield criterion, the sliding yield shear stress of the plate can be described as $\tau=\sigma_{Y} / \sqrt{3}$. The work done by the sliding yield shear stress can be described by Equation (4), as found in reference no. 21:

$$
W_{\mathrm{M}}=2 \pi R \frac{\sigma_{y}}{\sqrt{3}} \int_{0}^{h_{\mathrm{t}}} x \mathrm{~d} x=\frac{\pi}{\sqrt{3}} R \sigma_{y} h_{\mathrm{t}}^{2}
$$

In addition, there is also a part of the energy loss in the process of the fragment impacting the thin plate, which includes the energy loss caused by elastoplastic waves, the loss of heat during the fragment penetration, the energy consumption of plastic deformation of the plate, etc. To simplify the calculation, the energy loss can be calculated through an empirical formula: ${ }^{22}$

$$
W_{\mathrm{L}}=2 c e_{\mathrm{f}} R^{3} \sigma_{y}\left(\frac{h_{\mathrm{t}}}{r}\right)^{\mathrm{d}}
$$

where $c$ and $d$ are empirical constants, $e_{\mathrm{f}}$ is the fracture strain of uniaxial tensile.

For the work done by the shock wave, the energy can be described as

$$
W=\frac{P_{0} I}{2 \rho_{0} C_{0}}
$$

where $P_{0}$ is the peak pressure of the shock wave, $\rho_{0}$ and $C_{0}$ are the initial density and sound speed of air in front of the wave, respectively, $I$ is specific impulse, it can be expressed as $I=\int_{0}^{\tau} P(S, t) \mathrm{d} t, \tau$ is positive time, $P(S, t)$ is the pressure function of shock wave, which is related to the distance $S$ and time $t$ of the shock wave propagation. Because the time is short, the change of shock wave loading can be simplified as a rectangular stress pulse

$$
P(S, t)=\left\{\begin{array}{cc}
P_{0} & 0 \leq t \leq \tau \\
0 & t>\tau
\end{array}\right.
$$

So the total impulse can be approximated as

$$
I=2 \pi \int_{0}^{R} \int_{0}^{t^{\prime}} S P_{0} \mathrm{~d} S \mathrm{~d} t=\pi R^{2} t^{\prime} P_{0}
$$

Where $t^{\prime}$ is the positive time in the measured pressure-time curve of the shock wave.

According to the law of the conservation of energy, the work done by the shock wave caused by the chemical reaction of the fragment and the energy absorbed by the plate during the fragment impacting the plate are all converted into the plastic deformation energy of the thin plate. So the peak value of the shock wave pressure can be calculated as

$$
P_{0}=\sqrt{\frac{2 \rho_{0} C_{0}\left(0.5 R^{2} \sigma_{y} h_{\mathrm{t}}-W_{\mathrm{G}}-W_{\mathrm{M}}-W_{\mathrm{L}}\right)}{\pi R^{2} t^{\prime}}}
$$

where $P_{0}$ is the reflected shock wave suffered by the plate. When the incident shock wave is less than $0.8 \mathrm{MPa}$, the overpressure value can be written as $P_{0}^{\prime}=1 / 2 \cdot P_{0}$, whereas if the incident shock wave is between $0.8 \mathrm{Mpa}$ and $5 \mathrm{Mpa}$, the overpressure value can be written as $P_{0}^{\prime}=1 / 8 \cdot P_{0}$.

After the implosion, the shock wave pressure reaches its maximum instantaneously. Since the plate is very thin and the velocity of the fragment is very high, the attenuation of the shock wave in the plate can be ignored. It is considered that the attenuation of the shock wave all occurs in the air medium, so the shock wave pressure at a certain distance after the plate can be expressed as

$$
P_{\mathrm{m}}=P_{0}^{\prime} \cdot \exp \left(-\frac{L}{\alpha}\right)+C
$$

where $L$ is the distance of the shock wave attenuation, $\alpha$ is the attenuation coefficient of shock wave in the air medium, and its value depends the propagation distance, $C$, which is a constant.

\subsection{Deflection model}

During Zr-based metallic glass fragments impacting the thin plate, the plastic deformation of the plate is caused by the coupling effect of impact loading and explosion loading, and the process is complicated. In order to analyze the deflection of the plate, it is assumed that the plate is an ideal elastic-plastic material, which satisfies the Von-Mises yield criterion, and the plate is completely fixed and restrained around its dimensions. The center of the plate is taken as the coordinate origin, the plate size is $2 a \times 2 b \times h_{t} \mathrm{~mm}^{3}$, as shown in Figure 6 .

When the shock wave generated after the implosion of the fragment impacts on the plate, the deflection surface function of the plastic deformation of the plate can be expressed as

$$
\left\{\begin{array}{l}
u=u_{0} \sin \frac{\pi x}{a} \cos \frac{\pi y}{2 b} \\
v=v_{0} \cos \frac{\pi x}{2 a} \sin \frac{\pi y}{b} \\
w=w_{0} \cos \frac{\pi x}{2 a} \cos \frac{\pi y}{2 b}
\end{array}\right.
$$

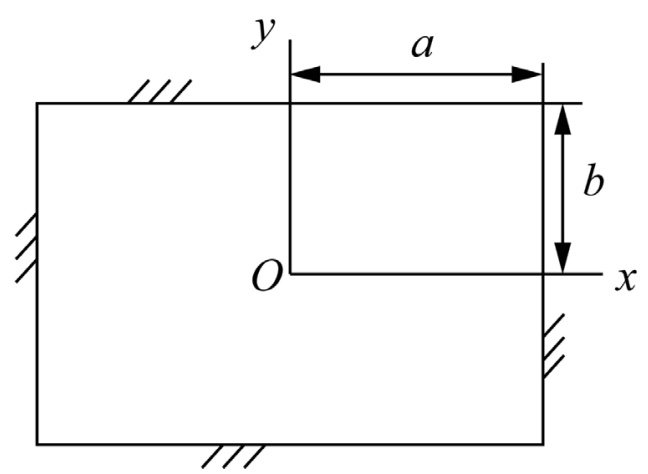

Figure 6: Schematic diagram of the structure of the constrained plate 
where $u, v$ and $w$ are displacements in the $x, y$ and $z$ directions, respectively. $u_{0}$ and $v_{0}$ are the maximum displacements in the $x$ and $y$ directions, respectively, $w_{0}$ is the deflection of plate in the direction of $z . a$ and $b$ are distances from the center to both edges of the plate. http://fanyi.baidu.com/

Assuming that the shock wave pressure is evenly distributed in the plane of the thin plate, the strain components along the $x$ and $y$ directions of the plate under plane stress can be written with Equation (12), as given in reference no. 23:

$$
\left\{\begin{array}{l}
\varepsilon_{x}=\frac{\partial u}{\partial x}+\frac{1}{2}\left[\frac{\partial w}{\partial x}\right]^{2} \\
\varepsilon_{y}=\frac{\partial v}{\partial y}+\frac{1}{2}\left[\frac{\partial w}{\partial y}\right]^{2} \\
y_{x y}=\frac{\partial u}{\partial y}+\frac{\partial v}{\partial x}+\left[\frac{\partial w}{\partial x}\left[\frac{\partial w}{\partial y}\right]\right.
\end{array}\right.
$$

The low-carbon steel plate is an isotropic homogeneous material, which meets the Von-Mises criterion, and the plastic deformation energy of the plate can also be described as

$$
\left.W=h s u b t \int_{-a}^{+a+b} \int_{-b}^{b} \sigma_{x}\left(\varepsilon_{y}+\varepsilon_{y}\right)+\frac{\sigma_{y}}{\sqrt{3}} \gamma_{x y}\right] \mathrm{d} x \mathrm{~d} y
$$

Based on above equations, the deflection of the plate can be deduced as

$$
w_{0}=\frac{k}{\pi} \sqrt{\frac{\left(\frac{P_{0} I}{2 \rho_{0} C_{0}}+W_{\mathrm{G}}+W_{\mathrm{M}}+W_{\mathrm{L}}\right)}{\sigma_{0} h_{\mathrm{t}}}}
$$

where $k$ is the correction coefficient, which is related to the constraint condition around the thin plate.

Table 2: Parameters setting

\begin{tabular}{|c|c|}
\hline Parameters & Values \\
\hline$\sigma_{Y}(\mathrm{GPa})$ & 0.4 \\
\hline$R(\mathrm{~mm})$ & $15 \sim 20$ \\
\hline$\rho_{t}\left(\mathrm{~g} \mathrm{~cm}^{-3}\right)$ & 7.8 \\
\hline$r(\mathrm{~mm})$ & 4 \\
\hline$c$ & 1.188 \\
\hline$d$ & 1.413 \\
\hline$e_{f}$ & 1.30 \\
\hline$\rho_{0}\left(\mathrm{~g} \mathrm{~cm}^{-3}\right)$ & $1.184 \times 10^{-3}$ \\
\hline$C_{0}\left(\mathrm{~m} \mathrm{~s}^{-1}\right)$ & 340 \\
\hline$\alpha\left(\mathrm{m}^{-1}\right)$ & $1 / 0.082$ \\
\hline$C$ & 0 \\
\hline$a\left(\mathrm{~mm}^{2}\right)$ & 150 \\
\hline$b\left(\mathrm{~mm}^{2}\right)$ & 150 \\
\hline$k$ & 0.92 \\
\hline
\end{tabular}

Using Equations from (1) to (14) and the experimental results given in Table $\mathbf{1}$, the values of the variables and parameters used in the calculations are shown in Table 2. Take the $2^{\text {nd }}$ and $3^{\text {rd }}$ experiments as examples, the calculated results are shown in Table 3, which is basically consistent with the experimental data, and the deviation is in an acceptable range. It shows that the shock wave pressure and deflection evaluation engineering models are valid when $\mathrm{Zr}$-based metallic glass fragments impact the thin plate.

Table 3: Comparison of experimental data and calculated results

\begin{tabular}{|c|c|c|c|c|c|c|}
\hline \multirow{2}{*}{ Shot\# } & \multicolumn{2}{|c|}{ Pressure peak (MPa) } & \multicolumn{3}{c|}{ Deflection (mm) } \\
\cline { 2 - 7 } & $\begin{array}{c}\text { Experi- } \\
\text { mental } \\
\text { data }\end{array}$ & $\begin{array}{c}\text { Calcu- } \\
\text { lated } \\
\text { results }\end{array}$ & $\begin{array}{c}\text { Devi- } \\
\text { ation }\end{array}$ & $\begin{array}{c}\text { Experi- } \\
\text { mental } \\
\text { data }\end{array}$ & $\begin{array}{c}\text { Calcu- } \\
\text { lated } \\
\text { results }\end{array}$ & $\begin{array}{c}\text { Devi- } \\
\text { ation }\end{array}$ \\
\hline 2 & 0.04 & 0.035 & $12.5 \%$ & $15-20$ & 18 & $10 \%$ \\
\hline 3 & 0.05 & 0.046 & $8 \%$ & $20-25$ & 22 & $12 \%$ \\
\hline
\end{tabular}

\section{CONCLUSIONS}

Ballistic impact experiments have been performed to investigate the energy-release behavior of $\mathrm{Zr}$-based metallic glass fragments with a density of $5.8 \mathrm{~g} \cdot \mathrm{m}^{-3}$, and sizes of $\phi 8 \mathrm{~mm} \times 8 \mathrm{~mm}$.

When impacting the thin plate of low-carbon steel at enough velocity, the Zr-based metallic glass fragments would initiate deflagration with a bright flame, due to exothermic chemical reaction and released energy during penetration.

The energy-release rate depends on the impact velocity of the fragment and the thickness of the plate. When a 3-mm-thick plate was hit at $1560 \mathrm{~m} \mathrm{~s}^{-1}$ and a 2-mm-thick plate was hit at $1348 \mathrm{~m} \mathrm{~s}^{-1}$, the impact response is stronger than the other cases. The higher the impact velocity and the thinner the plate is, the more intense is the chemical reaction.

The chemical energy-release behavior of the Zr-based metallic glass fragments can be characterized by the parameters obtained after impacting, such as shock wave pressure, reaming radius, and deflection of the thin plate. The penetration hole diameter is about 5 times the diameter of the fragment, there is an obvious radial reaming effect, and the damage pattern of ductile reaming was formed.

Based on the energy-conservation law, the engineering models of the shock wave pressure and the deflection are developed. The calculated results agree well with the experimental. data, which can provide a reliable basis for the evaluation of the impact response and energy release of Zr-based metallic glass materials.

Zr-based bulk metallic glasses are well known materials, however, the experimental data on the impact-based reactivity of Zr-based metallic glass is limited, and the corresponding reactivity mechanism is less well understood. Consequently, a quantitative estimation of the released chemical energy of Zr-based metallic glasses deserves further investigations in the future. 


\section{Acknowledgment}

The work was supported by National Natural Science Foundation of China under Grant no. 11802141 and 11772160.

\section{REFERENCES}

${ }^{1}$ A. Inoue, Bulk amorphous alloys, Amorphous and nanocrystalline materials, Springer, Berlin, Heidelberg 2001, 1-51, doi:10.1007/ 978-3-662-04426-1_1

${ }^{2}$ W. H. Wang, C. Dong, C. H. Shek, Bulk metallic glasses, Mater Sci Eng, Reports, 44 (2004) 2-3, 45-89, doi:10.1016/j.mser.2004.03.001

${ }^{3} \mathrm{M}$. W. Chen, A brief overview of bulk metallic glasses, NPG Asia Mater, 3 (2011) 9, 82, doi:10.1038/asiamat.2011.30

${ }^{4} \mathrm{~A}$. Inoue, Recent progress of Zr-based bulk amorphous alloys, Science reports of the Research Institutes, Tohoku University. Ser. A, Physics, chemistry and metallurgy, 42 (1996) 1, 1-11

${ }^{5}$ K. S. N. S. Idury, B. S. Murty, J. Bhatt, Thermodynamic modeling and composition design for the formation of $\mathrm{Zr}-\mathrm{Ti}-\mathrm{Cu}-\mathrm{Ni}-\mathrm{Al}$ high entropy bulk metallic glasses, Intermetallics, 65 (2015), 42-50, doi:10.1016/j.intermet.2015.04.007

${ }^{6}$ J. H. Chen, M. Q. Jiang, Y. Chen, L. H. Dai, Strain rate dependent shear banding behavior of a $\mathrm{Zr}$-based bulk metallic glass composite, Mater Sci Eng A, 576 (2013), 134-139, doi:10.1016/j.msea. 2013.03.082

${ }^{7}$ S. R. Cheng, C. J. Wang, M. Z. Ma, D. D. Shan, B. Guo, Mechanism for microstructural evolution induced by high temperature deformation in Zr-based bulk metallic glasses, J Alloy Compd, 676 (2016), 299-304, doi:10.1016/j.jallcom.2016.03.145

${ }^{8}$ C. Liu, V. Roddatis, P. Kenesei, R. Maaß, Shear-band thickness and shear-band cavities in a Zr-based metallic glass, Acta Mater, 140 (2017), 206-216, doi:10.1016/j.actamat.2017.08.032

${ }^{9}$ P. Thurnheer, F. Haag, J. F. Löffler, Time-resolved measurement of shear-band temperature during serrated flow in a Zr-based metallic glass, Acta Mater, 115 (2016), 468-474, doi:10.1016/j.actamat. 2016.05.008

${ }^{10}$ M. Zhou, J. X. Zhou, J. Wei, M. Yang, L. Q. Ma, Enhanced glass-

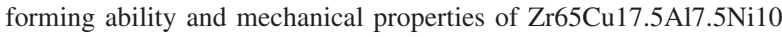
metallic glass by adding Fe, J Non-Cryst Solids, 455 (2017), 1-5, doi:10.1016/j.jnoncrysol.2016.05.004

${ }^{11}$ N. B. Hua, W. Z. Chen, Enhancement of glass-forming ability and mechanical property of $\mathrm{Zr}$-based $\mathrm{Zr}$-Al-Ni bulk metallic glasses with addition of Pd, J Alloy Compd, 693 (2017), 816-824, doi:10.1016/ j.jallcom.2016.09.263

${ }^{12}$ J. W. Qiao, Y. Zhang, P. Feng, Q. M. Zhang, G. L. Chen, Strain rate response of mechanical behaviors for a Zr-based bulk metallic glass matrix composite, Mater Sci Eng A, 515 (2009) 1-2, 141-145, doi:10.1016/j.msea.2009.02.043

${ }^{13}$ M. C. Li, M. Q. Jiang, S. Yang, F. Jiang, L. He, J. Sun, Effect of strain rate on yielding strength of a $\mathrm{Zr}$-based bulk metallic glass, Mater Sci Eng A, 680 (2017), 21-26, doi:10.1016/j.msea. 2016.10.081

${ }^{14}$ E. V. Boltynjuk, D. V. Gunderov, E. V. Ubyivovk, M. A. Monclús, L. W. Yang, J. M. Molina-Aldareguia, A. I. Tyurinf, A. R. Kilmametovg, A. A. Churakovabc, A. Yu. Churyumovh, R. Z. Valiev, Enhanced strain rate sensitivity of Zr-based bulk metallic glasses subjected to high pressure torsion, J Alloy Compd, 747 (2018), 595-602, doi:10.1016/j.jallcom.2018.03.018

${ }^{15}$ M. Q. Jiang, Y. P. Wei, G. Wilde, L. H. Dai, Explosive boiling of a metallic glass superheated by nanosecond pulse laser ablation, Appl phys lett, 106 (2015) 2, 021904, doi:10.1063/1.4905928

${ }^{16}$ H. L. Ren, X. J. Liu, J. G. Ning, Microstructure and mechanical properties of W-Zr reactive materials, Mater Sci Eng A, 660 (2016), 205-212, doi:10.1016/j.msea.2016.02.009

${ }^{17}$ C. M. Huang, S. Li, S. X. Bai, Quasi-static and impact-initiated response of Zr55Ni5A110Cu30 alloy, J Non-Cryst Solids, 481 (2018), 59-64, doi:10.1016/j.jnoncrysol.2017.10.011

${ }^{18}$ P. Luo, Z. Wang, C. Jiang, L. Mao, Q. Li, Experimental study on impact-initiated characters of $\mathrm{W} / \mathrm{Zr}$ energetic fragments, Mater Design, 84 (2015), 72-78, doi:10.1016/j.matdes.2015.06.107

${ }^{19}$ C. T. Wang, Y. He, C. Ji, Y. He, W. Han, X. C. Pan, Investigation on shock-induced reaction characteristics of a Zr-based metallic glass, Intermetallics, 93 (2018), 383-388, doi:10.1016/j.intermet.2017. 11.004

${ }^{20}$ G. G. Corbett, S. R. Reid, W. Johnson, Impact loading of plates and shells by free-flying projectiles: a review, Int J Impact Eng, 18 (1996) 2, 141-230, doi:10.1016/0734-743X(95)00023-4

${ }^{21}$ W. C. Qian Perforation mechanics, National Defend Industry Press, Beijing 1984, 280-287, 326-334

${ }^{22}$ Z. G. Jiang, S. Y. Zeng, J. P. Zhou, Analyses of critical impact energy for plugging failure of thin metallic plates, Eng Mech, 21 (2004) 5, 203-208

${ }^{23}$ C. Zheng, X. S. Kong, W. G. Wu, F. Liu, The elastic-plastic dynamic response of stiffened plates under confined blast load, Int J Impact Eng, 95 (2016), 141-153, doi:10.1016/j.ijimpeng.2016.05.008 